\title{
Focal epithelial hyperplasia in a Brazilian family
}

\author{
Hiperplasia epitelial focal em uma família brasileira
}

\author{
Raniel Fernandes Peixoto \\ Gabriela Monteiro de Araújo* \\ Rafaela Monteiro de Araújo ${ }^{* * *}$ \\ Valéria Damasceno Silvestre \\ Ana Myriam Costa de Medeiros ${ }^{* * * *}$
}

\begin{abstract}
Focal Epithelial Hyperplasia (FEH) or Heck's disease is a rare and benign condition characterized by cell proliferation in the squamous epithelium, which is manifested clinically as verrucous projections. It is associated with Human Papillomavirus (HPV) subtype 13 or 32 , and it is often observed in children, young adults, and middle aged individuals, as well as some ethnic groups such as Indians and Eskimos, which suggests a possible hereditary influence. Objective: knowing that FEH is a rare disease among the Brazilian population, this article reports a case of FEH in a Brazilian family. Case report: a 27 year-old woman was assisted in the Department of Dentistry of the Federal University of Rio Grande do Norte (UFRN) showing round, plane, and well-defined lesions localized in the oral cavity, with an evolution of six years. Lesions underwent incisional biopsy, and the microscopic analysis revealed epithelial changes such as epithelium hyperplasia and prominent acanthosis. These histopathologic findings were consistent with the clinical hypothesis of FEH. Final considerations: this report reinforces the need for an accurate clinical assessment, so dentists are able to recognize, diagnose, and treat FEH in their own patients.
\end{abstract}

Keywords: Focal epithelial hyperplasia. Heck's disease. Human papillomavirus.

\section{Introduction}

The focal epithelial hyperplasia (FEH) or Heck's disease is a benign and relatively rare condition associated with human papillomavirus (HPV) subtype 13 or $32^{1-7}$. It was initially reported in literature in 1965 by Archard, Heck and Stanley, who observed oral mucosa lesions in American Indian children. It was originally described in Eskimos and ethnic groups from the North, South, and Central American Indian ancestry ${ }^{8-12}$, but it is currently recognized worldwide ${ }^{2}$.

Primarily, FEH is a disease of children, adolescents, and young adults. In some populations up to $40 \%$ of children are affected ${ }^{2,6}$. It is clinically characterized by multiple, soft circumscribed nodule elevations or small raised papules on the oral mucosa that often coalesce ${ }^{1-3,5-8}$. The lesions are asymptomatic and may be found by routine examination. Their color is usually pink or sometimes white ${ }^{2,6,7}$, and their diameter is $2-10 \mathrm{~mm}^{1,2}$. All areas of the oral cavity may be affected, but the lesions are most common on labial and buccal mucosa, and the ton$\mathrm{gue}^{2,7,8}$, and less frequent in the floor of the mouth, soft palate, and oropharynx. A high incidence in close communities and among family members indicates infectious pathogenesis ${ }^{8}$.

\footnotetext{
DDS, MSc Student, Department of Dental Materials and Prosthodontics, Ribeirão Preto Dental School, University of São Paulo, Ribeirão Preto, SP, Brazil. DDS, MSc Student, Department of Dentistry, Federal University of Rio Grande do Norte, Natal, RN, Brazil.

* DDS, Department of Dentistry, Federal University of Rio Grande do Norte, Natal, RN, Brazil.

DDS, MSc, PhD, Professor, Department of Dentistry, Federal University of Rio Grande do Norte, Natal, RN, Brazil.
} 
The histological features are epithelial hyperplasia, a sharply marked zone of epithelial acanthosis without formation of well-defined projections of epithelium, and the lesion contains minimal connective tissue papillae. Occasionally, cells' nuclei containing coarsely clumped heterochromatin resembling a mitotic figure may be observed, hence they are called "Mitosoid bodies",,2,7,13,14. Virus-like particles have been observed in lesional keratinocytes, and viral antigens have been detected by immunohistochemistry ${ }^{1,14}$.

The present article reports a case of family $\mathrm{FEH}$, aiming to educate and inform general dental practitioners so they are be able to recognize, diagnose, and manage FEH in their own patients.

\section{Case report}

A 27 year-old, non-white woman was referred to the Department of Dentistry of the Federal University of Rio Grande do Norte (UFRN) because of a lesion that was painless to palpation in her oral cavity, which had spontaneously appeared 6 years before.

Nodules were observed upon intraoral exam. Their surface was smooth, mostly sessile, rounded shaped and sometimes merged, their color was similar to the mucosa. The lesions were firm on palpation, coated with an apparently regular mucosa without ulceration or inflammation, with sizes ranging from 0.5 to $1 \mathrm{~cm}$, and were located on the labial mucosa left (Figura 1A) and lip vermillion (Figura 1B).

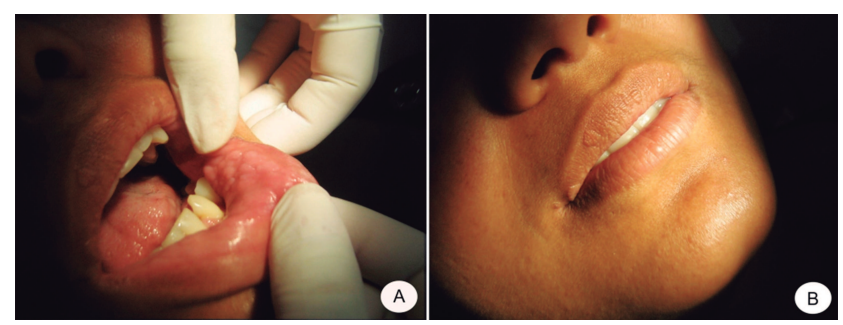

Figure 1 - Clinical appearance of the focal epithelial hyperplasia: multiple pink papules in the lower lip mucosa (A), and prominent, well-defined lesions in the lip vermillion (B).

When asked about her ethnic origin, the patient reported not to be indigenous descendant, and most of her relatives (a brother and a son) had similar lesions in the oral cavity (Figura 2A and 2B).

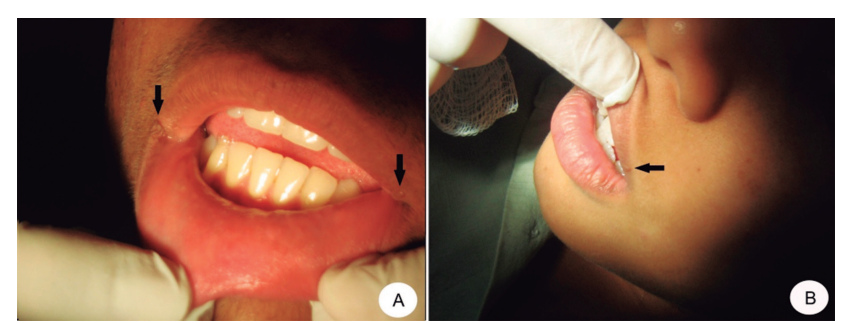

Figure 2 - Clinical appearance of the focal epithelial hyperplasia in descendants: prominent, well-defined lesions in the labial commissure (brother) (A), and in the lip vermillion (son) (B).
The clinical diagnosis was FEH, and incisional biopsy was performed on the labial mucosa. Microscopic examination revealed epithelium showing hyperplasia with deep papillomatous projections and prominent acanthosis (Figura 3). These histopathologic findings associated with clinical features of the lesion were consistent with the hypothesis of FEH.

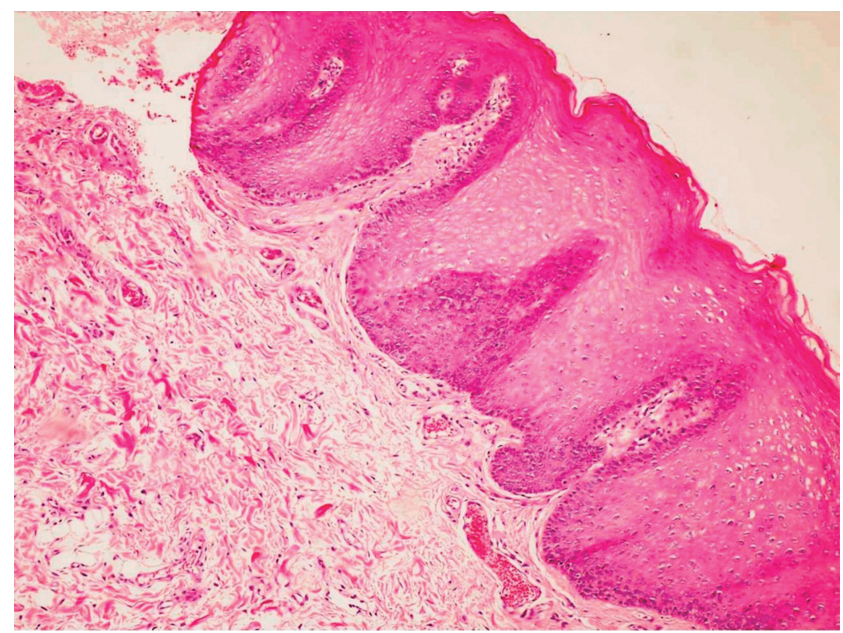

Figure 3 - Photomicrograph of focal epithelial hyperplasia showing epithelium with hyperplasia with deep papillomatous projections and prominent acanthosis ( $H / E-40 \times)$

The patient was informed of the benign nature of the lesions, which were not removed because of their large number. The patient had a one-year follow-up during which no clinical alteration of the lesions was observed.

\section{Discussion}

Focal Epithelial Hyperplasia is a relatively rare lesion ${ }^{1-7}$ first described in $1965^{11}$. Retrospective studies show that FEH has a wide frequency range from one geographic region to another, from $0.002 \%$ up to a prevalence of $40 \%$ in certain populations, as described by Barnes et al. ${ }^{2}$

Dos Santos et al. ${ }^{16}$ stated that FEH was the most prevalent lesion of the oral mucosa among Waimiri Atroari Indians, reaching 21\% with no differences among genders or different age groups.

Subtypes 13 and 32 of the HPV are known to be the main etiological agents of $\mathrm{FEH}^{1,2,6-8}$, however, information about the natural history of FEH is still incomplete, so it is not known why some lesions spontaneously retreat in some people and persist for a long time in others ${ }^{8}$.

This disease is an uncommon entity that occasionally affects young and middle-aged adults ${ }^{2,7,17}$. There is a predominance of the disease in women and certain breeds such as the Eskimos and native Americans ${ }^{1,4,6,13,18}$, however some cases have been reported in Caucasians $\mathbf{s}^{9,19}$, and in individuals with mean age above 45 years $^{19}$. This predominan- 
ce in certain ethnic groups and the existence of familiar cases ${ }^{14,20}$, as reported in this article, suggest a genetic predisposition ${ }^{2,7,14,20}$. Considering the case here presented, the patient profile is consistent with that described in literature.

From a clinical standpoint, FEH is presented in the form of multiple well-defined papules, which are slightly elevated, and their color varies from white to regular mucosa. It is asymptomatic and may affect any region of the oral mucosa, however it is more frequent in the labial mucosa, tongue, and cheek $^{2,3,6-8}$. All these clinical features are compatible with the case described.

An important aspect that should be considered is the differential diagnosis of FEH with other lesions that affect the oral cavity, such as inflammatory fibrous hyperplasia, inflammatory papillary hyperplasia, verruciform xanthoma, verrucous carcinoma, Cowden disease, and condylomata acuminata ${ }^{6,17}$.

In this context, the first three lesions mentioned emerge in reaction to the presence of an identifiable irritant. Verrucous carcinoma is a tumor that affects older individuals, and its epidemiological characteristics are similar to those found in oral carcinomas. Cowden's disease is typical of an older age group, and fibroepithelial polyps presents more consistency, less mobility, and different intraoral topography ${ }^{21}$. Differential diagnosis is very important to condylomata acuminata, as it is also caused by HPV, and its isolated lesions are very similar. However, the lesions found in FEH tend to be flatter and more numerous, adding the fact that the location of these lesions in the labial and buccal mucosa are very typical ${ }^{6,7,22}$.

Microscopically, FEH's trademark is an nodule with considerable acanthosis of the oral epithelium. The thickening of the epithelium extends to the outer surface of the lesion. There is not formation of well-defined projections of epithelium, and the lesion contains minimal connective tissue papillae. Other lesions occasionally demonstrate an altered nucleus that resembles a mitotic figure (mitosoid bodies) $)^{1,2,6,7,12}$.

Generally, histopathological findings described in this case confirm those in literature, distinguishing condylomata acuminata lesions and other cells, due to the presence and absence of mitosoid epithelial projections in the external surface of the epithelium $^{23}$.

Considering the clinical and epidemiological characteristics that differentiate the $\mathrm{FEH}$ lesions mentioned above, as well as histopathological features, it was possible to confirm the diagnosis of $\mathrm{FEH}$ in this case, excluding the need to perform an analysis by immunohistochemistry or in situ hybridization to detect the presence of HPV in the lesion.

Multiple therapeutic alternatives are proposed for FEH, such as simply monitoring the case, since the disease tends to resolve spontaneously and/or may persist for many years until surgical treatment, which is only indicated for diagnostic purposes, aesthetics, or when the lesions interfere with mastication and are constantly subjected to trauma ${ }^{1,21,24}$. However, there are alternatives for treatment, such as cryotherapy, laser therapy, cauterization, and the use of topical treatments such as retinoic acid or interferon ${ }^{6,7,25}$.

There are published reports of spontaneous retreat after months or years ${ }^{2,7,26,27}$. Because of the absence of symptoms and pain, and the presence of a large number of lesions, this case of patient monitoring was chosen. Up to now there is no published reports of neoplastic transformation ${ }^{2}$, and the case has been followed for 2 years in the Department of Dentistry of UFRN, although there was no regression of the lesion.

The recurrence of FEH or the appearance of new lesions is unpredictable and therefore follow-up is required. Moreover, it is not known whether recurrence of the lesions is related to new infections, changes in the immune response, or a latent infection ${ }^{8}$.

\section{Final considerations}

This report reinforces the need of accurate clinical assessment so dentists are able to recognize, diagnose, and treat FEH in their own patients.

\section{Resumo}

A hiperplasia epitelial focal (HEF) ou doença de Heck é uma doença benigna, rara e caracterizada por proliferação celular no epitélio escamoso, que se manifesta clinicamente como projeções verrucosas. É associada com o papilomavírus (HPV), subtipo humano 13 ou 32, e, muitas vezes, é observada em crianças, adultos jovens e pessoas de meia-idade, bem como em alguns grupos étnicos, como os índios e esquimós, o que sugere uma possível influência hereditária. Objetivo: sabendo que a HEF é uma doença rara na população brasileira, este artigo relata um caso de HEF em uma família brasileira. Relato de caso: paciente feminina, de 27 anos de idade, foi atendida no Departamento de Odontologia da Universidade Federal do Rio Grande do Norte (UFRN), mostrando lesões bem definidas, arredondadas, planas, localizadas em cavidade oral e com uma evolução de seis anos. As lesões foram submetidas a biópsia incisional, e a análise microscópica revelou alterações epiteliais, como hiperplasia do epitélio e acantose proeminente. Esses resultados histopatológicos foram consistentes com a hipótese clínica de HEF. Considerações finais: este relatório reforça a necessidade de uma avaliação precisa da clínica, para dentistas serem capazes de reconhecer, diagnosticar e tratar HEF em seus próprios pacientes.

Palavras-chave: Hiperplasia epitelial focal. Doença de Heck. Papilomavírus humano. 


\section{References}

1. Neville BW, Damm DD, Allen CM, Bouquot JE. Patologia oral e maxilofacial. In: Neville BW, Damm DD, Allen CM, Bouquot JE. Patologia epitelial. 3. ed. Rio de Janeiro: Elsevier; 2009. p. 368-9

2. Barnes L, Eveson JW, Reichart P, Sidransky D. Pathology and genetics of head and neck tumors. WHO classification of tumors series. In: Odell EW. Papillomas. Focal epithelial hyperplasia. Lyon: IARC Press; 2005. p. 184.

3. Kumaraswamy KL, Vidhya M. Human papilloma virus and oral infections: an update. J Cancer Res Ther 2011; 7:120-7.

4. Delgado Y, Torrelo A, Colmenero I, Zambrano A. Focal epithelial hyperplasia. Actas Dermosifiliogr 2005; 96:697-9.

5. Mosannen-Mozaffari P, Falaki F, Amirchaghmaghi M, Pakfetrat A, Dalirsani Z, Saghafi-Khadem S. Multifocal epithelial hyperplasia, a rare oral infection in Asia: report of twelve cases in Iran. Med Oral Patol Oral Cir Bucal 2010; 15:591-5.

6. Hashemipour MA, Shoryabi A, Adhami S, Honarmand HM. Extensive focal epithelial hyperplasia. Arch Iran Med 2010; $13: 48-52$.

7. Del Boz J, Funez R. Hiperplasia epitelial focal em España. Piel: Form Cont Dermat 2011; 26:491-4.

8. Durso BC, Pinto JM, Jorge J Jr, de Almeida OP. Extensive focal epithelial hyperplasia: case report. J Can Dent Assoc 2005; 71:769-71

9. Pilgard G. Focal epithelial hyperplasia. Report of nine cases from Sweden and review of the literature. Oral Surg Oral Med Oral Pathol 1984; 57:540-3.

10. Acevedo A, Gonzales GM, Nelson JF. Focal epithelial hyperplasia. Oral Surg Oral Med Oral Pathol 1981; 51:524-6.

11. Archard HO, Heck JW, Stanley HR. Focal epithelial hyperplasia: an unusual oral mucosal lesion found in Indian children. Oral Surg Oral Med Oral Pathol 1965; 20:201-12.

12. Ledesma-Montes C, Garces-Ortiz M, Hernandez-Guerrero JC. Chnicopathological and immunocytochemical study of multifocal epithelial hyperplasia. J Oral Maxillofac Surg 2007; 65:2211-7.

13. Vera-Iglesias E, Garcia-Arpa M, Sánchez-Caminero P, Romero-Aguilera G, Cortina de la Calle P. Focal epithelial hyperplasia. Actas Dermosifiliogr 2007; 98:621-3.

14. Alvarez-Santullano CAV, Hernandez-Nunez A, Castano A, Medrano RM, Guijarro SC, Martinez JB. Multifocal epithelial hyperplasia: a familial case. An Pediatr (Barc) 2010; 73:357-60.

15. Praetori F. Geographical aspects of oral focal epithelial hyperplasia. Pathol Microbiol (Basel) 1973; 39:204-13.

16. dos Santos PJB, Bessa CFN, de Aguiar MCF, do Carmo MAV. Cross-sectional study of oral mucosal conditions among a central Amazonian Indian community, Brazil. J Oral Pathol Med 2004; 33:7-12.

17. Terezhalmy GT, Riley CK, Moore WS. Clinical images: focal epithelial hyperplasia (Heck's disease) - histopathologic examination and DNA hybridization tests are essential for diagnosis. Quintessence Int 2001; 32:664-5.
18. Bennett LK, Hinshaw M. Heck's disease: diagnosis and susceptibility. Pediatr Dermatol 2009; 26:87-9.

19. Axell T, Hammarstrom L, Larsson A. Focal epithelial hyperplasia in Sweden. Acta Odontol Scand 1981; 39:201-8.

20. Hall C, McCullough M, Angel C, Manton D. Multifocal epithelial hyperplasia: a case report of a family of Somalian descent living in Australia. Oral Surg Oral Med Oral Pathol Oral Radiol Endod 2010; 109:E14-E18.

21. Borborema-Santos CM, Castro MM, Santos PJ, Talhari S, Astolfi-Filho S. Oral focal epithelial hyperplasia: report of five cases. Braz Dent J 2006; 17:79-82.

22. Yasar S, Mansur AT, Serdar ZA, Goktay F, Aslan C. Treatment of focal epithelial hyperplasia with topical imiquimod: report of three cases. Pediatr Dermatol 2009; 26:465-8.

23. Jayasooriya PR, Abeyratne S, Ranasinghe AW, Tilakaratne WM. Focal epithelial hyperplasia (Heck's disease): report of two cases with PCR detection of human papillomavirus DNA. Oral Dis 2004; 10:240-3.

24. Martins WD, De Lima AAS, Vieira S. Focal epithelial hyperplasia (Heck's disease): report of a case in a girl of Brazilian Indian descent. Int J Paediatr Dent 2006; 16:65-8.

25. Akyol A, Anadolu R, Anadolu Y, Ekmekci P, Gurgey E, Akay N. Multifocal papillomavirus epithelial hyperplasia: successful treatment with CO2 laser therapy combined with interferon alpha-2b. Int J Dermatol 2003; 42:733-5.

26. Segura-Saint-Gerons R, Toro-Rojas M, Ceballos-Salobreña A, Aparicio-Soria JL, Fuentes-Vaamonde H. Focal epithelial hyperplasia: a rare disease in our area. Med Oral Patol Oral Cir Bucal 2005; 10:128-31.

27. Gonzlez LBS, Gonzlez HL, Bobadilla DA. Prevalencia de patologa buccaly de estructuras relacionadas en pacientes geriatricos de la regín I del Estado de México. Rev ADM 1995; 52:129-37.

\section{Corresponding author:}

Raniel Fernandes Peixoto

Rua Sete de Setembro, 983, Apto 111

Centro

14010-180 Ribeirão Preto, SP, Brazil

Phone/Fax: +55 (16) 8116-4104

E-mail: raniel87@gmail.com

Recebido: 06/08/2013.Aceito: 25/09/2013. 